\title{
The $5^{\prime}$ insulin gene polymorphism and the genetics of vascular complications in Type 1 (insulin-dependent) diabetes mellitus
}

\author{
L.J. Raffel ${ }^{1,2}$, C. M. Vadheim ${ }^{2}$, M.-P. Roth $^{3}$, R. Klein ${ }^{4}$, S. E. Moss ${ }^{4}$ and J. I. Rotter ${ }^{2}$ \\ ${ }^{1}$ Division of Human Genetics, Departments of Pediatrics, and Obstetrics and Gynecology, University of Maryland School of Medicine, \\ Baltimore, Maryland, \\ ${ }^{2}$ Medical Genetics Birth Defects Center, Departments of Medicine and Pediatrics, Cedars-Sinai Medical Center, and UCLA School of \\ Medicine, Los Angeles, California, USA, \\ ${ }^{3}$ Immunologie et Immunogenetique Humaine, INSERM U100, CHU Purpan, Toulouse, France \\ ${ }^{4}$ Department of Ophthalmology, University of Wisconsin Medical School, Madison, Wisconsin, USA
}

\begin{abstract}
Summary. Recent data suggest genetic contributions to the microvascular complications of Type 1 (insulin-dependent) diabetes mellitus. Most research has focused on the HLA region, and the potential role of other genetic loci has not been adequately explored. We examined the possible relationship between DNA polymorphisms in the region $5^{\prime}$ to the insulin gene on chromosome 11 and diabetic nephropathy. This was done by comparison of those diabetic patients homozygous for class 1 alleles at the $5^{\prime}$ insulin gene polymorphism locus to $1 / 3$ heterozygotes in a well-characterized series of 324 insulin-requiring diabetic patients from the Wisconsin Epidemiologic Study of Diabetic Retinopathy. Proteinuria (defined as $\geq 0.3 \mathrm{~g}$ protein/l urine), was used as suggestive evidence for diabetic nephropathy. Hypertension, a frequent associated finding in diabetic patients with nephropathy, was defined as a blood pressure greater than 140/90 or a history of
\end{abstract}

previous treatment of hypertension. The two genotypically defined groups did not differ from each other in regard to sex ratio, age at diagnosis, age at examination, duration of diabetes, body mass, $\mathrm{HbA}_{\mathrm{lc}}$ or $\mathrm{C}$-peptide. The $1 / 1$ group had a higher prevalence of proteinuria, $29 \%$ as compared to $16.2 \%$ in other genotypes $(p<0.05)$. There was no significant difference in the frequency of hypertension between the two genotypic groups. This finding suggests that the $5^{\prime}$ insulin gene polymorphism may be associated with risk for nephropathy, but the pathophysiologic mechanism remains unclear.

Key words: Type 1 (insulin-dependent) diabetes mellitus, diabetic nephropathy, $5^{\prime}$ insulin gene polymorphism, heredity.
During the past 20 years, many studies have demonstrated the importance of genetic factors in susceptibility to Type 1 (insulin-dependent) diabetes mellitus [1]. In recent years, attention has started to also focus on the contribution of genetic loci to the natural history of Type 1 diabetes, including the occurrence and severity of diabetic complications $[1,2]$. In particular, several studies have suggested an increased incidence of diabetic retinopathy in Type 1 diabetic patients who carry the HLA-DR4 allele [1-4]. Until now however, there has been relatively little attention paid to the potential role of non-HLA loci in diabetes natural history and complications. We wish to report the results of our investigations of the $5^{\prime}$ insulin gene polymorphism and its role in one of the vascular complications of Type 1 diabetes, diabetic nephropathy.

The $5^{\prime}$ insulin gene polymorphism is a region of DNA length variability immediately $5^{\prime}$ to the insulin gene itself [5]. Although the function of this region remains unknown, a number of case-control studies have detected an association between small insertions, called class 1 alleles, and Type 1 diabetes [6-8]. The present study was under- taken to assess the possible role of the $5^{\prime}$ insulin gene polymorphism in specific complications of Type 1 diabetes.

\section{Subjects and methods}

Study sample

A cross-sectional population-based cohort of individuals with Type 1 diabetes, with an onset of disease prior to 30 years of age, was recruited between 1 July 1979 and 30 June 1980 as part of the Wisconsin Epidemiologic Study of Diabetic Retinopathy (WESDR1), as reported previously $[9,10]$. All subjects consented to participate following explanation of the purpose of the study. The study protocol was approved by the institutional review board at the University of Wisconsin. In a follow-up study of genetic and autoimmune factors involved in diabetic retinopathy, 440 randomly selected members of the original 996-member cohort were re-investigated between 1984 and 1986 (WESDR2). In addition to a thorough ophthalmological examination to assess the presence and severity of diabetic retinopathy, venous blood was obtained from all subjects for the study of a number of genetic markers, including HLA-A, B, C and DR alleles and the $5^{\prime}$ insulin gene polymorphism. Unequivocal 
determination of the $5^{\prime}$ insulin gene polymorphism DNA fragment size, as well as blood pressure data from WESDR1 and WESDR2, was available in 324 of the original 440 individuals studied. The group of 324 does not differ from other members of the original cohort in terms of age at diagnosis, age at examination, systolic or diastolic blood pressure, history of hypertension, sex, degree of diabetic retinopathy, presence of proteinuria or family history of diabetes (all $p$-values for comparisons 0.10 or greater by chi-square or $t$-test). This group of 324 Caucasian Type 1 diabetic subjects was used for the present analysis.

Proteinuria was defined as $\geq 0.3 \mathrm{~g}$ protein $/$ urine and its presence was used as suggestive evidence for nephropathic changes. Hypertension was defined as a blood pressure greater than $140 / 90$ at the time of examination or a history of previous treatment for hypertension.

\section{5'Insulin gene polymorphism}

Leucocytes were separated from $10 \mathrm{ml}$ of venous blood using a Histopaque-1077 (Sigma Chemical Co., St. Louis, Mo., USA) gradient or a modified ammonium chloride/ammonium bicarbonate buffer system $[11,12]$. DNA was extracted using the method of Denaro et al. [13], and digested with the restriction enzyme Bgl I according to manufacturer's instructions. The samples were subjected to electrophoresis in $0.9 \%$ agarose gels and the DNA transferred to nitrocellulose filters by Southern's technique [14]. Prehybridization and hybridization of the DNA-containing filters were performed by the method described by Wahl et al. [15]. Hybridization was performed using a ${ }^{32} \mathrm{P}$-human insulin probe, which was prepared from an Hinc/ II-Bgl I fragment of the plasmid phins 214 grown in the bacteria HB101. Phins 214 contains a 1650 base pair fragment which includes the human insulin gene and $585^{\prime}$ and $1173^{\prime}$ flanking mucleotides [5]. The probe was kindly provided by Dr. G. Bell. Classification of the DNA polymorphism is based on restriction endonuclease fragment size. Fragments of $2800 \pm 300$ base pairs are termed class 1 (small) alleles; those of $3500 \pm 300$ base pairs are class 2 (intermediate) alleles, and those greater than 3900 base pairs are class 3 (large) alleles.

\section{Statistical analysis}

All comparisons were tested for statistical significance using standard methods. Given the ordered nature of the variables, the loglikelihood ratio test for contingency tables was applied, with the statistic $G$ being distributed as a chi-square statistic, with degrees of freedom $(\mathrm{r}-1)(\mathrm{c}-1)$, where $\mathrm{r}$ and $\mathrm{c}$ are the numbers of the rows and columns respectively $[16,17]$.

\section{Results}

The relationship between proteinuria and the $5^{\prime}$ insulin polymorphism was evaluated for both the initial patient examination in 1980-1982 (WESDR1) and the follow-up visit in 1984-1986 (WESDR2). Those individuals homozygous for class 1 alleles were compared to those who were either heterozygous (1/3) or homozygous for class 3 alleles. At initial examination in WESDR1 (Table 1), individuals homozygous for class 1 were significantly more likely to have proteinuria $(p<0.05)$. By the time of the re-evaluation in WESDR2 (Table 2), the increased risk for proteinuria associated with the homozygosity for class 1 alleles was more evident, with $29 \%$ of those with a $1 / 1$ genotype having proteinuria $(0.3 \mathrm{~g} / \mathrm{l}$ or greater $)$, while only $16 \%$ of those with a class 3 allele had proteinuria $(p<0.05)$. Alternatively, of the individuals with proteinuria, $75 \%$ had a $1 / 1$ genotype, while this was true
Table 1. Proteinuria prevalence: Wisconsin Epidemiologic Study of Diabetic Retinopathy 1 (1979-1980)

\begin{tabular}{|c|c|c|c|c|}
\hline \multirow{2}{*}{$\begin{array}{l}5^{\prime} \text { insulin gene } \\
\text { polymorphism }\end{array}$} & \multicolumn{4}{|c|}{ Proteinuria severity } \\
\hline & None or trace & $0.3-1.0 \mathrm{~g} / \mathrm{l}$ & $3.0+\mathrm{g} / \mathrm{I}$ & Total \\
\hline $1 / 1$ & $155(77 \%)$ & $38(19 \%)$ & $9(4 \%)$ & 202 \\
\hline Any 3 & $100(88 \%)$ & $12(10 \%)$ & $2(2 \%)$ & 114 \\
\hline \multicolumn{5}{|c|}{$\mathrm{G}^{2}=6.15,2$ degrees of freedom, $p<0.05$} \\
\hline \multicolumn{5}{|c|}{${ }^{\mathrm{a}} \mathrm{G}^{2}$ is the log-likelihood chi-square statistic } \\
\hline
\end{tabular}

Table 2. Proteinuria prevalence: Wisconsin Epidemiologic Study of Diabetic Retinopathy 2 (1984-1986)

\begin{tabular}{lrrrr}
\hline $\begin{array}{l}5^{\prime} \text { insulin gene } \\
\text { polymorphism }\end{array}$ & \multicolumn{4}{l}{ Proteinuria severity } \\
\cline { 2 - 5 } & None or trace & $0.3-1.0 \mathrm{~g} / \mathrm{l}$ & $3.0+\mathrm{g} / \mathrm{l}$ & Total \\
\hline $1 / 1$ & $137(71 \%)$ & $46(24 \%)$ & $10(5 \%)$ & 193 \\
Any 3 & $98(84 \%)$ & $16(14 \%)$ & $3(2 \%)$ & 117 \\
$\mathrm{G}^{2}=6.80,2$ degrees of freedom, $p<0.05$ & & \\
$\mathrm{G}^{2}$ is the $\log$-likelihood chi-square statistic & & \\
\hline
\end{tabular}

Table 3. Progression of proteinuria: Wisconsin Epidemiologic Study of Diabetic Retinopathy 1 (1979-1980) --> 2 (1984-1986)

\begin{tabular}{lrll}
\hline $5^{\prime}$ insulin gene polymorphism & No change & Worse & Total \\
\hline $1 / 1$ & $157(81 \%)$ & $35(18 \%)$ & 192 \\
Any 3 & $99(89 \%)$ & $13(11 \%)$ & 112 \\
$G^{2}=2.42,1$ degree of freedom, $p=0.12$ & & \\
$G^{2}$ is the log-likelihood chi-square statistic & & \\
\hline
\end{tabular}

Table 4. Hypertension and the insulin gene polymorphism

\begin{tabular}{|c|c|c|c|}
\hline \multicolumn{4}{|c|}{ Wisconsin Epidemiologic Study of Diabetic Retinopathy 1(1979-1980) } \\
\hline & Normal blood pressure & Hypertensive & Total \\
\hline$\overline{1 / 1}$ & $160(78 \%)$ & $45(22 \%)$ & 205 \\
\hline Any 3 & $99(83 \%)$ & $20(17 \%)$ & 119 \\
\hline \multicolumn{4}{|c|}{$\mathrm{G}^{2}=1.27,1$ degree of freedom, $p=0.26$} \\
\hline \multicolumn{4}{|c|}{ Wisconsin Epidemiologic Study of Diabetic Retinopathy 2(1984-1986) } \\
\hline & Normal blood pressure & Hypertension & Total \\
\hline$\overline{1 / 1}$ & $156(77 \%)$ & $47(23 \%)$ & 203 \\
\hline Any 3 & $96(79 \%)$ & $25(21 \%)$ & 121 \\
\hline \multicolumn{4}{|c|}{$\mathrm{G}^{2}=0.27,1$ degree of freedom, $p=0.60$} \\
\hline \multicolumn{4}{|c|}{$\mathrm{G}^{2}$ is the log-likelihood chi-square statistic } \\
\hline
\end{tabular}

of only $58 \%$ of individuals with traces of or no proteinuria.

Although most individuals showed no change in degree of proteinuria between WESDR1 and 2, those who did were more likely to have worsening rather than improvement in their proteinuria. To determine if the $5^{\prime}$ insulin polymorphism played a role in progression of nephropathy, change in status between the two examinations was assessed for the two insulin gene polymorphism groups (Table 3 ). Of those individuals homozygous for class 1 alleles, $18 \%$ had worsening of their proteinuria, whereas only $11 \%$ of those with a class 3 allele had progression of their proteinuria. Although the difference does not reach statistical significance, the trend seen in Table 3 is also consistent with the two cross-sectional observations of WESDR1 and WESDR2. 
In an effort to assess whether the $5^{\prime}$ insulin gene polymorphism was associated primarily with renal disease or secondarily via hypertensive damage to the kidney, the relationship between hypertension and the insulin gene polymorphism was also examined (Table 4). There was no difference in the genotype frequencies in those with or without hypertension, either at initial examination or at the follow-up 4 years later.

\section{Discussion}

The aetiology of nephropathy in Type 1 diabetes remains unclear. One possibility which has been considered is that diabetic nephropathy is solely the result of the metabolic derangements which occur in diabetes. Supporting this idea is the observation that clinical renal disease is uncommon before 10 years duration of diabetes, with a peak incidence not occurring until between 15 and 20 years after disease onset [18-20]. Not all patients with long duration of diabetes develop nephropathy, however, suggesting that factors other than strictly metabolic derangements must also be implicated $[19,21]$. A possibility which must be entertained is that at least some of these additional risk factors may be genetic.

Supporting the concept that genetic factors are likely to be important in the development of diabetic nephropathy is the recent report by Seaquist et al. [22] regarding the occurrence of nephropathy in diabetic sibling pairs. Only $17 \%$ of Type 1 diabetic siblings of diabetic probands without nephropathy, but $83 \%$ of Type 1 diabetic siblings of diabetic probands with nephropathy, had evidence of nephropathy themselves. While a common environment could explain some of the increased risk in siblings, shared genetic factors must also be considered as an explanation. In contrast to diabetic retinopathy, where numerous studies have addressed the possibility of genetic predisposition, few studies have evaluated the role of genetic factors in diabetic nephropathy. The one candidate locus which has been studied previously is HLA, with no clearly identified association to nephropathy $[2,23]$.

The results of the present study suggest an association of class 1 alleles of the $5^{\prime}$ insulin gene polymorphism with nephropathy, as indicated by the presence of proteinuria. The progression of nephropathy in Type 1 diabetic patients also appears to be influenced by the insulin gene polymorphism, as individuals carrying the class 1 allele were more likely to show worsening of their proteinuria between WESDR1 and 2 than were those with class 3 alleles. Although it was not possible to directly document the presence of diabetic nephropathy with 24-h urine collections in this population-based study, the finding of proteinuria in random urine specimens is highly suggestive of renal disease. It is well-established that proteinuria is a reliable indicator of early renal disease, and that diabetic subjects with microalbuminuria are 20 times more likely to progress to clinical nephropathy than those without it $[24,25]$.

Given the apparent association of the 5 insulin gene polymorphism with nephropathy, several mechanistic ex- planations might be invoked. The first is that the nephropathy might be mediated through an atherogenic gene linked to the insulin gene locus. This initially seems plausible, given the previous reports of an association of the $5^{\prime}$ insulin gene polymorphic region and atherosclerosis [26-29]. This possibility can be excluded, however, since the association with nephropathy found in the current study is with the class 1 allele of the $5^{\prime}$ insulin gene polymorphic locus, in contrast to the class 3 association previously reported for both atherosclerosis and hypertriglyceridaemia [26-29].

Another potential mechanism is that nephropathy might occur as a consequence of hypertensive damage to the kidney. Hypertension has been demonstrated to be an independent risk factor for the development of diabetic nephropathy, rather than simply a secondary complication of pre-existing renal damage $[19,24,30,31]$. In addition, it is clear that this predisposing hypertension has genetic components $[30,32]$. In the present study, this possibility was examined, as shown in Table 4. Our results suggest that the class 1 alleles of the $5^{\prime}$ insulin gene polymorphism are not associated with a predilection to hypertension among diabetic subjects. Therefore, the increased risk for nephropathy associated with the class 1 allele must be mediated through a different mechanism, unrelated to the pathophysiology of hypertension.

Genetic predisposition to diabetic complications may be mediated by genes which themselves predispose to the development of diabetes, or by genes which are unrelated to disease aetiology. In the case of the $5^{\prime}$ insulin gene polymorphism, the latter possibility appears more probable, although controversy remains. Several population studies have identified an association of the class 1 alleles with Type 1 diabetes [33-35]. Results of family linkage studies, however, are inconclusive [35-40]. The results of our present study suggest that this region is important in at least one of the complications associated with Type 1 diabetes. Further studies are needed to confirm this association with nephropathy, following which it will be necessary to study the exact mechanism(s) by which the $5^{\prime}$ insulin gene polymorphic region contributes to this complication.

Acknowledgements. This study was supported in part by NIH grants EY05369 and EY03083, a grant from the Stuart Foundations, and the Cedars-Sinai Board of Governors' Chair in Medical Genetics (JIR).

\section{References}

1. Rotter JI, Vadheim CM, Rimoin DL (1990) Genetics of diabetes mellitus. In: Rifkin H, Porte D (eds) Ellenberg and Rifkin's Diabetes Mellitus, Theory and Practice. Elsevier, New York, pp. 378-413

2. Barbosa J, Saner B (1984) Do genetic factors play a role in the pathogenesis of diabetic microangiopathy? Diabetologia 27: $487-492$

3. Dornan TL, Ting A, McPherson CK et al. (1982) Genetic susceptibility to the development of retinopathy in insulin-dependent diabetes. Diabetes 31: 226-231

4. Secchi A, Fabio G, Pontiroli AE et al. (1989) HLA antigens in insulin-dependent diabetes: Their role on development of re- 
mission phase and degenerative complications of diabetes. DNM 2:3-9

5. Bell GI, Karam JH, Rutter WJ (1981) Polymorphic DNA region adjacent to the $5^{\prime}$ end of the human insulin gene. Proc Natl Acad Sci USA 78: 5759-5763

6. Bell GI, Horita S, Karam JH (1984) A polymorphic locus near the human insulin gene is associated with insulin-dependent diabetes mellitus. Diabetes 31: 176-183

7. Owerbach D, Nerup J (1982) Restriction fragment length polymorphism of the insulin gene in diabetes mellitus. Diabetes 31 : 275-277

8. Hitman GA, Tarn AC, Winter RM et al. (1985) Type 1 (insulindependent) diabetes and a highly variable locus close to the insulin gene on chromosome 11. Diabetologia 28: 218-222

9. Klein R, Klein BEK, Moss SE, DeMets DL, Kaufman I, Voss PS (1984) Prevalence of diabetes in Southern Wisconsin. Am J Epidemiol 119: 54-61

10. Klein R, Klein BEK, Moss SE, Davis MD, DeMets DL (1984) The Wisconsin Epidemiologic Study of Diabetic Retinopathy. II: Prevalence and risk of diabetic retinopathy when age at diagnosis is less than 30 years. Arch Ophthalmol 102: 520-526

11. Boyum A (1968) Separation of leukocytes from blood and bone marrow. Scand J Clin Invest 21 (Suppl 92): 77-89

12. Kan YW, Dozy AM, Trecartin R, Todd B (1979) Identification of a nondeletion effect in thalassemia. New Engl J Med 297: 10811084

13. Denaro M, Blanc H, Johnson MJ et al. (1981) Ethnic variation of Hpa I endonuclease cleavage patterns of human mitochondrial DNA. Proc Natl Acad Sci USA 78: 5768-5772

14. Southern EM (1975) Detection of specific sequences among DNA fragments separated by gel electrophoresis. J Molec Biol 98: 503-517

15. Wahl GM, Stern M, Stark GR (1979) Efficient transfer of large DNA fragments from agarose gels to diazobenzyloxymethylpaper and rapid hybridization by using dextran sulfate. Proc Natl Acad Sci USA 76: 615-619

16. Zar JF (1984) Biostatistical Analysis, 2nd edn. Prentice-Hall, Englewood Cliffs, New Jersey

17. Fleiss JL (1982) Statistical Methods for Rates and Proportions, 2nd edn. John Wiley and Sons, New York

18. Kofoed-Enevoldsen A, Borch-Johnsen K, Kreiner S, Deckert T (1987) Declining incidence of persistent proteinuria in Type 1 (insulin-dependent) diabetic patients in Denmark. Diabetes 36: 205-209

19. Hasslacher $\mathrm{CH}$, Stech W, Wahl P, Ritz E (1985) Blood pressure and metabolic control as risk factors for nephropathy in Type 1 (insulin-dependent) diabetes. Diabetologia 28: 6-11

20. Nyberg G, Larsson O, Attman P, Granerus G, Norden G (1985) Time as a risk factor in diabetic nephropathy. Diabetes Care 8: 590-593

21. Chazan BI, Balodimos MC, Ryan JR, Marble A (1970) Twentyfive to forty-five years of diabetes with and without vascular complications. Diabetologia 6: 565-569

22. Seaquist ER, Goetz FC, Rich S, Barbosa J (1989) Familial clustering of diabetic kidney disease. Evidence for genetic susceptibility to diabetic nephropathy. N Engl J Med 320: 11611165

23. Walton C. Dyer PA, Davidson JA, Harris R, Mallick NP, Oleeksy S (1984) HLA antigens and risk factors for nephropathy in Type 1 (insulin-dependent) diabetes mellitus. Diabetologia 27:3-7

24. Viberti GC, Walker JD (1988) Diabetic nephropathy: Etiology and prevention. Diabetes Metab Rev 4: 147-162
25. Mogensen CE, Christensen CK (1984) Predicting diabetic nephropathy in insulin-dependent patients. N Engl J Med 311: 89-93

26. Owerbach D, Johansen K, Billesbolle P, Poulsen S, Schroll M, Nerup J (1982) Possible association between DNA sequences flanking the insulin gene and atherosclerosis. Lancet ii: 12911293

27. Mandrup-Poulsen T, Owerbach D, Mortensen SA et al. (1984) DNA sequences flanking the insulin gene on chromsome 11 confer risk of atherosclerosis. Lancet i: 250-252

28. Jowett NI, Rees A, Williams LG et al. (1984) Insulin and apolipoprotein $\mathrm{A}-\mathrm{l} / \mathrm{C}-\mathrm{III}$ gene polymorphisms relating to hypertriglyceridaemia and diabetes mellitus. Diabetologia 27: 180-183

29. Jowett NI, Williams LG, Hitman GA, Galton DJ (1984) Diabetic hypertriglyceridaemia and related $5^{\prime}$ flanking polymorphism of the human insulin gene. Br Med J 288: 96-99

30. Viberti GC, Keen H, Wiseman MJ (1987) Raised arterial pressure in parents of proteinuric insulin dependent diabetes. $\mathrm{Br}$ Med J 295: 515-517

31. Mangili R, Bending JJ, Scott G, Li LK, Gupta A, Viberti GC (1988) Increased sodium-lithium countertransport activity in red cells of patients with insulin-dependent diabetes and nephropathy. N Engl J Med 318: 146-150

32. Krolewski AS, Canessa M, Warram JH et al. (1988) Predisposition to hypertension and susceptibility to renal disease in insulindependent diabetes mellitus. N Engl J Med 318: 140-145

33. Bell GI, Horita S, Karam JH (1984) A polymorphic locus near the human insulin gene is associated with insulin-dependent diabetes mellitus. Diabetes 31:176-183

34. Owerbach D, Nerup J (1982) Restriction fragment length polymorphism of the insulin gene in diabetes mellitus. Diabetes 31 : $275-277$

35. Hitman GA, Tarn AC, Winter RM et al. (1985) Type 1 (insulindependent) diabetes and a highly variable locus close to the insulin gene on chromosome 11. Diabetologia 28: 218-222

36. Cox NJ, Spielman RS (1989) The insulin gene and susceptibility to Type 1 diabetes. Genet Epidemiol 6: 65-69

37. Dizier M-H, Clerget-Darpoux F, Hochez J (1989) Segregation analysis of two genetic markers in Type 1 diabetes families under two locus models. Genet Epidemiol 6: 71-75

38. Donald JA, Barendse W, Cooper DW (1989) Linkage studies of HLA and insulin gene restriction fragment length polymorphisms in families with IDDM. Genet Epidemiol 6:77-81

39. Fimmers $R$, Neugebauer $M$, Dennert $J$, Wienker $T$, Baur MP (1989) Association and sibpair analysis for the HLA, Gm, Km, and insulin polymorphisms in multiplex IDDM families. Genet Epidemiol 6: 107-112

40. Cox NJ, Baker L, Spielman RS (1988) Insulin gene sharing in sib pairs with insulin-dependent diabetes mellitus: No evidence for linkage. Am J Hum Genet 42: 167-172

Received: 7 January 1991

and in revised form; 14 June 1991

Professor L.J.Raffel

Division of Medical Genetics

Cedars-Sinai Medical Center

8700 W. Beverly Boulevard

SSB-378

Los Angeles, California 90048

USA 